\title{
Identification of Potential Areas for Establishment of Plantations of Agave lechuguilla Torr. in Coahuila, Mexico
}

\author{
David Castillo-Quiroz*, Oscar Ulises Martínez-Burciaga, Diana Yemilet Ávila-Flores, \\ Francisco Castillo-Reyes, Juan David Sánchez-Chaparro \\ National Institute of Forestry, Agriculture and Livestock Research (INIFAP), Experimental Station Saltillo, \\ Saltillo, Mexico \\ Email: castillo.david@inifap.gob.mx
}

Received 10 July 2014; revised 22 August 2014; accepted 16 September 2014

Copyright @ 2014 by authors and Scientific Research Publishing Inc.

This work is licensed under the Creative Commons Attribution International License (CC BY). http://creativecommons.org/licenses/by/4.0/

(c) (i) Open Access

\begin{abstract}
Adverse weather conditions and intensive use for fiber production have caused decline of natural populations of Agave lechuguilla. By these reasons, it is important to develop a sustainable management of this specie to avoid this situation. One of the first steps is to establish forest plantations as an alternative to restore $A$. lechuguilla habitat and increase its range while at the same time indirectly reducing erosion rates. The aim of this study was to identify the potential areas for establishment of plantations of $A$. lechuguilla in the State of Coahuila, Mexico. Areas for planting establishment were selected according to multi-criteria analysis using Geographic Information System (GIS) Idrisi32 Ver 2.0 and 3.2 Arc.View. The analysis was based on comparison of climate and soil requirements in contrast to environmental conditions of the tested area. The evaluated variables were: soil type, texture, depth, average annual temperature, annual precipitation, elevation and slope. Results derive in potential area maps, geo-referenced and their distribution by Agricultural Development District. An area of 5 million 159,273 hectares was determined with potential for establishment of $A$. lechuguilla forest plantations in the State of Coahuila. It was concluded that, use of GIS is a reliable tool to determine potential areas for A. lechuguilla forest plantations, where this specie has higher probability of success in survival and biomass production. This study will support programs aimed to strengthen the economy of rural producers and also recover and preserve the arid state.
\end{abstract}

\section{Keywords}

Agave lechuguilla, Forest Plantations, Natural-Fiber, Geographical Information Systems

\footnotetext{
${ }^{*}$ Corresponding author.
}

How to cite this paper: Castillo-Quiroz, D., Martínez-Burciaga, O. U., Ávila-Flores, D. Y., Castillo-Reyes, F., \& SánchezChaparro, J. D. (2014). Identification of Potential Areas for Establishment of Plantations of Agave lechuguilla Torr. in Coahuila, Mexico. Open Journal of Forestry, 4, 520-526. http://dx.doi.org/10.4236/ojf.2014.45056 


\section{Introduction}

Natural fibers of Lechuguilla (Agave lechuguilla Torr.) are one of the most produced fibers around the world. This specie is a native succulent plant, distributed in arid and semi-arid areas of the Southern part of United States of America and Northern part of Mexico (Castillo et al., 2011). In Mexico, A. lechuguilla is distributed in the Coahuila, Chihuahua, Nuevo Leon, Durango, San Luis Potosi, Tamaulipas and Zacatecas States (Nobel \& Quero, 1986; Berlanga, 1991) and to lesser range in the center and south of the country (Marroquin et al., 1981). However, the main producing states of A. lechuguilla fiber are Coahuila, Tamaulipas, Nuevo Leon, Zacatecas and San Luis Potosi. The lechuguilla fiber with higher commercial quality and value is obtained from the growth bud, called "cogollo". This is formed by gentle leaves, grouped in the center, which contains lesser lignin than the lateral leaves (Castillo et al., 2005). For habitants of arid and semi-arid areas of Mexico, harvesting of lechuguilla fiber has great socioeconomic impact and for generations it has been a subsistence activity (Berlanga et al., 1992; Pando et al., 2004; Castillo et al., 2008). The 93\% of the national production of lechuguilla fiber is exported, generating a source of foreign exchange for the country. Because of this, Mexico is the only exporting country. Between 2003 and 2007 sales for \$350,000 dollars were recorded (SEMARNAT, 2010; Castillo et al., 2011). The fiber has application in the manufacture of brushes for various uses (Castillo et al., 2005).

In arid and semi-arid regions of the Coahuila State, agricultural soils have been used without previous studies where its potential uses and environment impact by different uses are determined. Use of land through agriculture, livestock and forestry is performed on an inadequate way, which has resulted in environmental degradation, an inefficient exploitation commercial and loss of natural resources, mainly soil and water. On the other hand, productive potential of crops such as corn and beans is low, mainly because of limited availability of water and soil degradation due to erosive action of natural factors and the human actions. Like many plant species from arid and semiarid regions of Mexico, lechuguilla has been subjected to excessive and irrational harvesting which has caused decline of natural populations, to the extent that, it is increasingly difficult to obtain raw material for fiber production. In addition, a decline in lechuguilla ecosystem has been observed which obligates to look for a sustainable production, involving methodologies from evaluation and management under natural conditions until domestication through techniques for establishment and agronomic management of commercial plantations (Velasco et al., 2009, Pando-Moreno et al., 2008, Castillo et al., 2008, Berlanga et al., 1991 and Berlanga et al., 1992). A key aspect that has been little considered and should be taken into account if results of this technology want to be maximized, is the agroecological aspect; the detailed factors of the physical environment which determine the species production potential, according to their physiological and morphological characteristics at the environment where it can be more productive. Therefore, these characteristics can be identified through technology applications for future plantings. This will allow high yields and a sustainable development. Based on the above, the aim of this study was to determine potential areas with high productive potential for establishment of commercial plantations of A. lechuguilla in the State of Coahuila, Mexico, based on attributes of each of the agro-weather factors that influence $A$. lechuguilla production.

\section{Materials and Methods}

\subsection{Study Area}

Arid and semiarid regions of Coahuila State were chosen to perform this study. This State is located in northeastern part of Mexico, between $24^{\circ} 32^{\prime}$ and $29^{\circ} 53^{\prime}$ North Latitude (LN) and $99^{\circ} 51^{\prime}$ and $103^{\circ} 68^{\prime}$ West Longitude (LW). Coahuila is the third largest state in the country with an area of 151,562 km² (INEGI, 2013), bordered in north by the United States of America, to the west by the State of Chihuahua, to the south with Zacatecas and San Luis Potosí, to the west and east with Durango and Nuevo León respectively (Figure 1).

\section{Subdivision of the Study Area}

Coahuila State is divided in 38 counties, which for this study purposes was subdivided into five regions based on the five regions of agricultural production, according to the regionalization by Secretary of Agriculture and Rural Development, Fisheries and Food (SAGARPA) which divides the State into five Rural Development Districts (Table 1). 


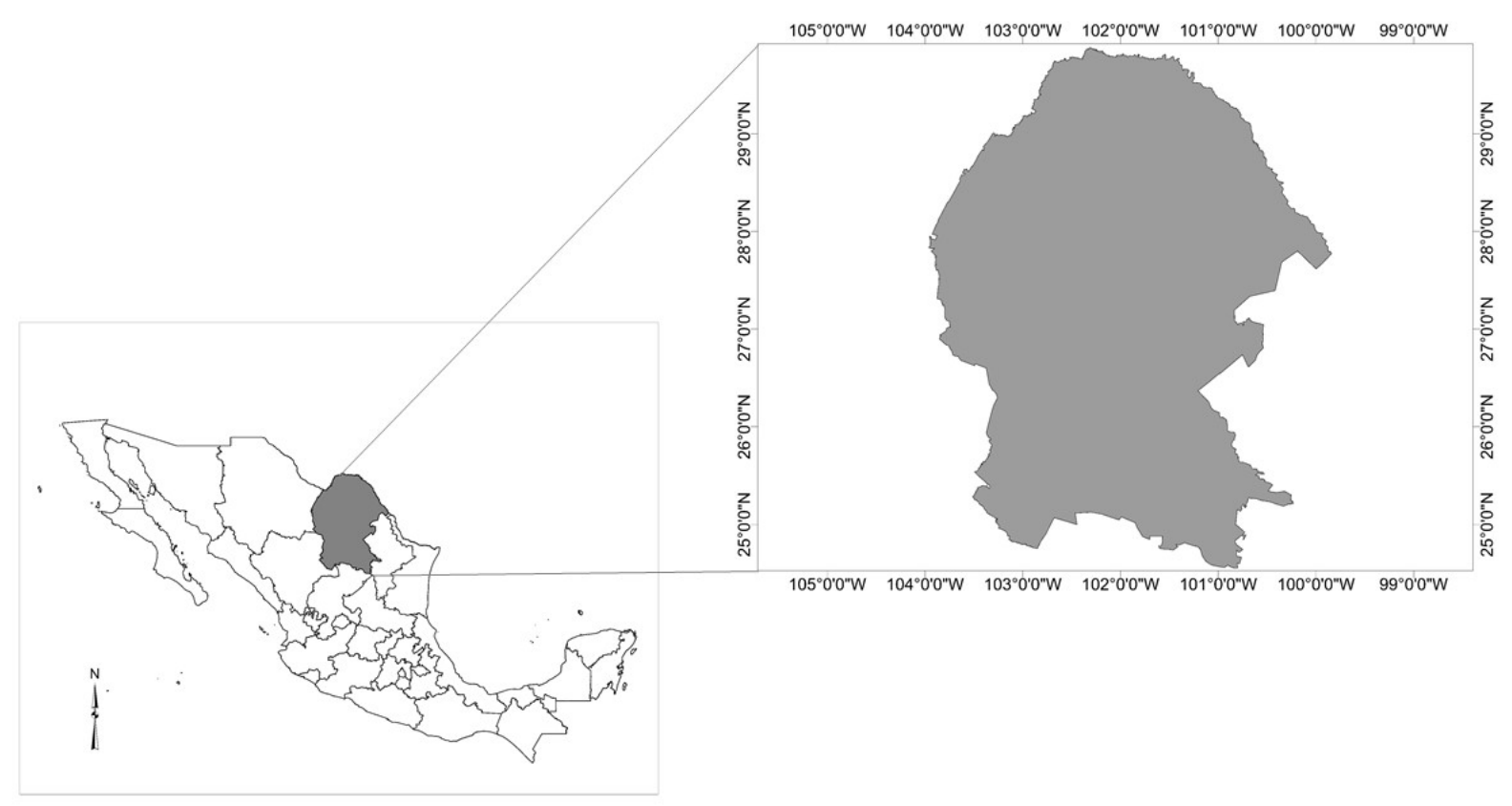

Figure 1. Geographical location of the study area in Coahuila, Mexico.

Table 1. Rural development districts and counties, according to the Ministry of Agriculture and Rural Development (SAGARPA).

\begin{tabular}{cr}
\hline District Rural Development & Municipalities \\
\hline DDR 001 & Acuña, Allende, Hidalgo, Jiménez, Nava, Piedras Negras, Morelos, Guerrero, Zaragoza and Villa Unión. \\
DDR 002 & Juárez, Múzquiz, Progreso, Sabinas and San Juan de Sabinas. \\
DDR 003 & Cuatro Ciénegas, Sierra Mojada, Ocampo, Candela, Monclova, Escobedo, Frontera, Abasolo, Castaños, \\
LDR 004 & Arteaga, General Cepeda, Parras de la Fuente, Ramos Arizpe and Saltillo. \\
DDR 005 & Matamoros, Francisco I. Madero, San Pedro, Torreón and Viesca. \\
\hline
\end{tabular}

\subsection{Selection Criteria for Determining Potential Area for Agave lechuguilla Torr. Establishment}

The criteria considered relevant to A. lechuguilla growth involved climatic, soil and topography aspects. These criteria were obtained through literature reviewing, particularly the work done by Eguiarte \& Silva 2001; Reyes et al., 2000; Gentry, 1985; Nobel \& Quero, 1986; Sheldon, 1980 and the research results by the National Institute of Forestry, Agriculture and Livestock (INIFAP) (Martínez et al., 2011; Martínez et al., 2010; Castillo et al., 2011; Castillo et al., 2008; Velasco et al., 2009; Narcia et al., 2012; Martinez \& Lara, 2003; Berlanga et al., 1991; Berlanga et al., 1992; Marroquín et al., 1981; Zapién, 1981). The minimum requirements established for determining the geographic areas with potential for planting and production of A. lechuguilla Torrare shown in Table 2.

\subsection{Determination of the Production Potential}

Weather parameters for identification of potential areas for the A. lechuguilla commercial plantations establishment consisted of a multi-criteria analysis conducted by the Geographic Information System (GIS) Idrisi 32 Ver 2.0 (Eastman, 1999). This analysis was based on comparison of climate and soil requirements of A. lechuguilla against environmental conditions of the study area according to the methodology proposed by Medina et al., (1997). The climatic parameters were obtained from the Climate Information System of the National Institute of Agricultural and Forestry Research (INIFAP), which come from a process of collection, management, analysis and interpretation of data on a daily base from maximum and minimum temperature, precipitation and evaporation, corresponding to meteorology station of ordinary type belonging to the network of stations of the National 
Table 2. Environmental requirements considered to assess areas potentially suitable for establishment of plantations of Agave lechuguilla Torr. in Coahuila.

\begin{tabular}{ccccc}
\hline Altitude m. s. n. m & Precipitation mm & Temperature ${ }^{\circ} \mathrm{C}$ & Slope $\%$ & Soil Texture \\
\hline $950-1990$ & $200-500$ & $16-26$ & $4-20$ & Media and course \\
\hline
\end{tabular}

Water Commission in Coahuila (CONAGUA). In addition, edaphic information, land use and topographic conditions were obtained from the cartography from National Institute of Statistics, Geography and Informatics (INEGI) at scale of 1:250,000. Identification and mapping of potential area derived from multi-criteria analysis was performed using Arc View GIS 3.2 software (ESRI, 1999). Starting from the thematic images produced by variable, was generated the cartography of each variable by exporting the images and converting them to vector by format "Shapefile", which were edited to obtain the general maps with potential areas and the number of hectares that they represented. Distribution of potential areas for forest plantations of A. lechuguilla in Coahuila was based on the regionalization made by Secretariat of Agriculture, Livestock and Rural Development, Fisheries and Food (SAGARPA) which divide the State into five Districts of Rural Development (Table 1).

\subsection{Validation of Potential Areas}

Field visits were performance to verify the specific points with potential for artificial establishment of the species under study, in order to check the proper ecological conditions for A. Lechuguilla growth and therefore, for establishment of plantations.

\section{Results and Discussion}

Combination of physical environment factors n the GIS software allowed generating aps with eo-referenced potential areas. Based on previously developed databases of climate, soil and topographic factors, the study allowed differentiating areas with similar environments characteristics in which A. lechuguilla could have better growth. In a first step, each of these physical factors was analyzed independently to determine its spatial distribution within the ranges required by A. lechuguilla. From binary map were indicating areas that are or are not within these ranges of lechuguilla growth. In this step, the combining factors and overlaying different maps resulted in binary maps on which it relied to quantify the potential surface for each of the Districts of State Rural Development.

\section{Area with Potential for Commercial Planting of Agave lechuguilla Torr. in Coahuila}

An area of 5159273.59 hectares with potential for plantations of A. lechuguilla was estimated. The district with the greatest potential area for plantation establishment was DDR 003 with a total superficial from 3029096.74 ha, followed by DDR 004 with 1074831.11 ha. At the county level, Ocampo stands out with a higher recording of surface potential with 1434878.11 ha, and the lowest record was the Frontera county with a surface with only 30.83 ha. Full results are shown in Table 3 and their geographical distribution is presented by District Rural Development in Figure 2.

According to the obtained results, over a third part of the State surface has agroclimatic characteristics required to produce A. lechuguilla with high potential, mainly in the western, central and south regions of the State, which is related to agro-climatic conditions of arid and semiarid ecosystems. Martínez et al., 2010; Martínez \& Lara (2003), and Nobel \& Quero, (1986) mentions that A. lechuguilla inhabits sites with a range of rainfall between 200 - $500 \mathrm{~mm}$, whose average value is not more than $300 \mathrm{~mm}$, another important factor is altitude above sea level which should ranges between 950 and 2300 meters, however the optimal conditions for establishment of plantations of A. lechuguilla ranging from 950 to 1990. In additions, this plant requires over $200 \mathrm{~mm}$ rainfall and average annual temperature ranges from $17^{\circ} \mathrm{C}$ to $26^{\circ} \mathrm{C}$ with $30^{\circ} \mathrm{C}$ as maximum and $10^{\circ} \mathrm{C}$ as a minimum, grows in shallow soils, stony ridges or, well, flat stony soils with good drainage conditions without salinity problems. It can be said that, few factors restricting the potential area of A. lechuguilla, perhaps altitude above sea level is the most extensively discriminate though; problems of low slope and soil salinity also take into greatly limiting its effect. The obtained results agree with those reported by Gentry, 1985 who said that the natural distribution of A. lechuguilla is located in the western and southeastern parts of the State. 
Table 3. Area of potential sites (ha) suitable for forest plantations of Agave lechuguilla Torr. in the Coahuila counties.

\begin{tabular}{ccc}
\hline District Rural Development & Counties & Area (ha) \\
\hline DDR 001 & Acuña & 130611.13 \\
& Zaragoza & 41244.59 \\
DDR 002 & Múzquiz & 96636.10 \\
& Progreso & 1643.28 \\
& Abasolo & 2254.44 \\
& Candela & 10148.21 \\
& Castaños & 116511.41 \\
& Cuatro Ciénegas & 536734.36 \\
& Escobedo & 497.96 \\
DDR 003 & Frontera & 30.83 \\
& Lamadrid & 36520.78 \\
& Monclova & 19235.632 \\
& Nadadores & 6735.56 \\
& Ocampo & 1434878.11 \\
& Sacramento & 6982.47 \\
& San Buenaventura & 245914.71 \\
& Sierra Mojada & 612652.27 \\
DDR 004 & Arteaga & 4054.78 \\
& General Cepeda & 177159.26 \\
& Parras de la Fuente & 564744.56 \\
& Ramos Arizpe & 308099.46 \\
& Saltillo & 20773.05 \\
& Foncisco I. Madero & 134734.03
\end{tabular}

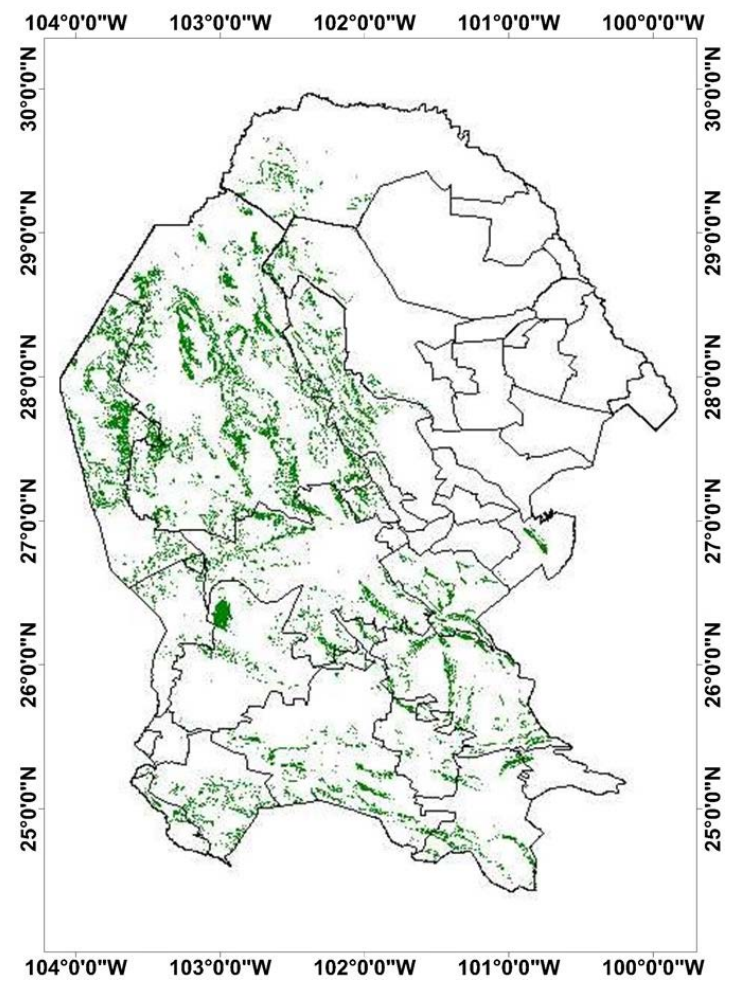

Figure 2. Areas with potential for establishment of forest plantations of lechuguilla (Agave lechuguilla Torr.) in Coahuila. 


\section{Conclusion}

We identified 5,159,273 hectares in the state of Coahuila that have favorable conditions for the establishment of A. lechuguilla, where the Rural Development District 003 has the largest area with potential for establishment of A. lechuguilla. This study will support programs aimed to strengthen the economy of rural producers in arid and semi-arid areas of the Coahuila State and also to recover and conserve natural populations and reduce erosion problems.

\section{References}

Berlanga, R. C. A. (1991). Producción y recuperación de lechuguilla (Agave lechuguilla Torr.) en poblaciones naturales. In III Simposio Nacional Sobre Ecología, Manejo y Domesticación de Plantas Útiles del Desierto, INIFAP, Saltillo, Coah, México.

Berlanga, R. C. A., González, L. L. A., \& Franco, L. H. (1992). Metodología para evaluación y manejo de lechuguilla en condiciones naturales. Folleto Técnico No. 1 SARH-INIFAP-CIRNE. Campo Experimental. “La Sauceda”, Saltillo, Coahuila, México, $22 \mathrm{p}$.

Castillo, Q. D., Berlanga, R. C. A., Pando, M. M., \& Cano, P. A. (2008). Regeneración del cogollo de Agave lechuguilla Torr., de cinco procedencias bajo cultivo. Revista Ciencia Forestal en México, 33, 27-40.

Castillo, Q. D., Berlanga, R. C. A., \& Cano, P. A. (2005). Recolección extracción y uso de la fibra de lechuguilla (Agave lechuguilla Torr.) en el estado de Coahuila. INIFAP-CIRNE. Campo Experimental Saltillo. Publicación Especial Núm. 6. Coahuila, México, 13 p.

Castillo, Q. D., Mares, A. O., \& Villavicencio, G. E. E. (2011). Lechuguilla (Agave lechuguilla Torr.) planta suculenta de importancia económica y social de las zonas áridas y semiáridas de México. Vol. 8, No. 2. Boletín de la Sociedad Latinoamericana y del Caribe de Cactáceas y otras Suculentas, 6-9.

Eastman, J. R. (1999). IDRISI32 Ver 2.0: Guide to GIS and Image Processing. Clark Labs, Clark University. Worcester, MA 01610-1477, USA.

Eguiarte, L. E., \& Silva, A. (2001). Ecología evolutiva de Agave lechuguilla: Variación geográfica ybiología reproductiva. XV Congreso Mexicano de Botánica. Los retos de la botánica mexicana en el presente siglo. Querétaro-Querétaro14-19.

ESRI (1999). ArcView GIS, Using ArcView GIS (340 p). Redlands, CA: Environmental Systems Research Institute Inc.

Gentry, S. H. (1985). Agaves of Continental North America. Tucson: The University of Arizona Press. 670 p.

Instituto Nacional de Estadística Geografía e Informática (INEGI) (2013). México en cifras. Información Nacional por Entidad Federativa (lastchecked 1 june 2014). http://www3.inegi.org.mx/sistemas/mexicocifras/

Martínez, B. O. U., \& Lara, G. G. J. (2003). Potencial productivo de áreas de temporal en el estado de Coahuila. Una propuesta de conversión productiva. INIFAP-CIRNE. Campo Experimental Saltillo. Publicación Especial Núm. 1. Coahuila, $89 \mathrm{p}$.

Marroquín, J. S., Borja, L. G., Velásquez, C. R., \& De la Cruz, J. A. (1981). Estudio ecológico dasonómico de las zonas áridas del norte de México. Publicación Especial Núm. 2. 2nd Edición, Instituto Nacional de Investigaciones Forestales. México, 166 p.

Medina, G., Ruiz C. G., Martínez, P. J. A., \& Ortiz, V. M. (1997). Metodología para la determinación del potencial productivo de especies vegetales. Agricultura Técnica en México, 23, 69-90.

Narcia, V. M., Castillo, Q. D., Vázquez R. J. A., \& Berlanga, R. C. A. (2012). Turno Técnico de la lechuguilla (Agave lechuguilla Torr.) en el noreste de México. Revista Mexicana de Ciencias Forestales, 3, 81-88.

Nobel, P. S., \& Quero, E. (1986). Environmental Productivity Indices for a Chihuahuan Desert CAM Plant, Agave lecheguilla. Ecology, 67, 1-11. http://dx.doi.org/10.2307/1938497

Pando, M. M., Eufracio, O., Jurado, E., \& Estrada, E. (2004). Post-Harvesting Growth of Lechuguilla (Agave lechuguilla Torr. Agavaceae) in Northeastern Mexico. Economic Botany, 58, 78-82.

Pando-Moreno, M., Pulido, R. R., Castillo, Q. D., Jurado, E., \& Jiménez, J. (2008). Estimating Fiber for Lechuguilla (Agave lecheguilla Torr., Agavaceae), a Traditional Non-Timber Forest Product in Mexico. Forest Ecology and Management, 255, 3686-3690.

Reyes A. J. A., Aguirre R. J., \& Peña, V. C. B. (2000). Biología y aprovechamiento de Agave lechuguilla. Torrey. Boletin de la Sociedad Botanica de Mexico, 67, 75-88.

Secretaría del Medio Ambiente y Recursos Naturales (SEMARNAT) (2010). Fichas de información comercial de productos forestales. Comisión Nacional Forestal y Fondos Mixtos para la Investigación, el Desarrollo y la Innovación Tecnológica Forestal. México City, 13 p. 
Sheldon, S. (1980). Ethnobotany of Agave lechuguilla and Yucca carnerosana in Mexico’s Zona Ixtlera. Economic Botany, 34, 376-390. http://dx.doi.org/10.1007/BF02858314

Velasco, B. E., Arredondo, G. A., Zamora-Martínez, M. C., \& Moreno, S. F. (2009). Modelos Predictivos para la Producción de Productos Forestales No Maderables: Lechuguilla. Manual Técnico Núm. 2. CENID-COMEF. INIFAP, México City, $56 \mathrm{p}$.

Zapién, B. M. (1981). Evaluación de la producción de ixtle de lechuguilla en cuatro sitios diferentes. Primera Reunión Regional sobre Ecología, Manejo y Domesticación de las Plantas Útiles del Desierto. Publicación Especial Núm. 31. Instituto Nacional de Investigaciones Forestales. SARH. México City, 385-389. 
Scientific Research Publishing (SCIRP) is one of the largest Open Access journal publishers. It is currently publishing more than 200 open access, online, peer-reviewed journals covering a wide range of academic disciplines. SCIRP serves the worldwide academic communities and contributes to the progress and application of science with its publication.

Other selected journals from SCIRP are listed as below. Submit your manuscript to us via either submit@scirp.org or Online Submission Portal.
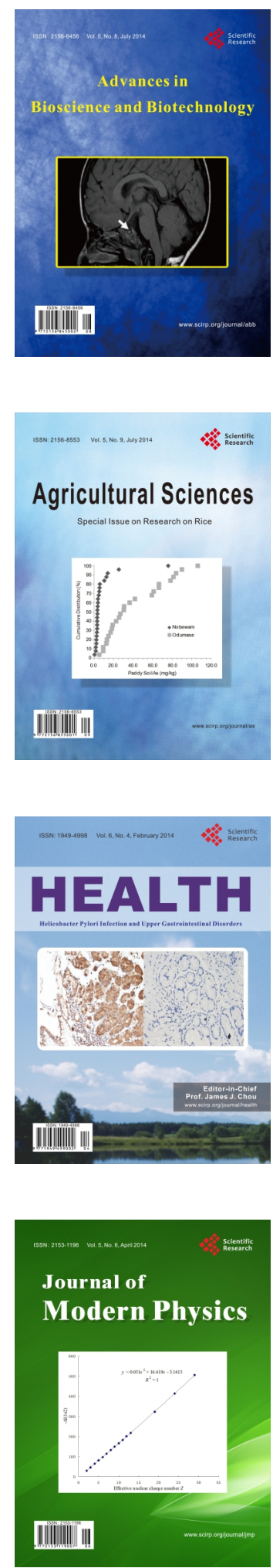
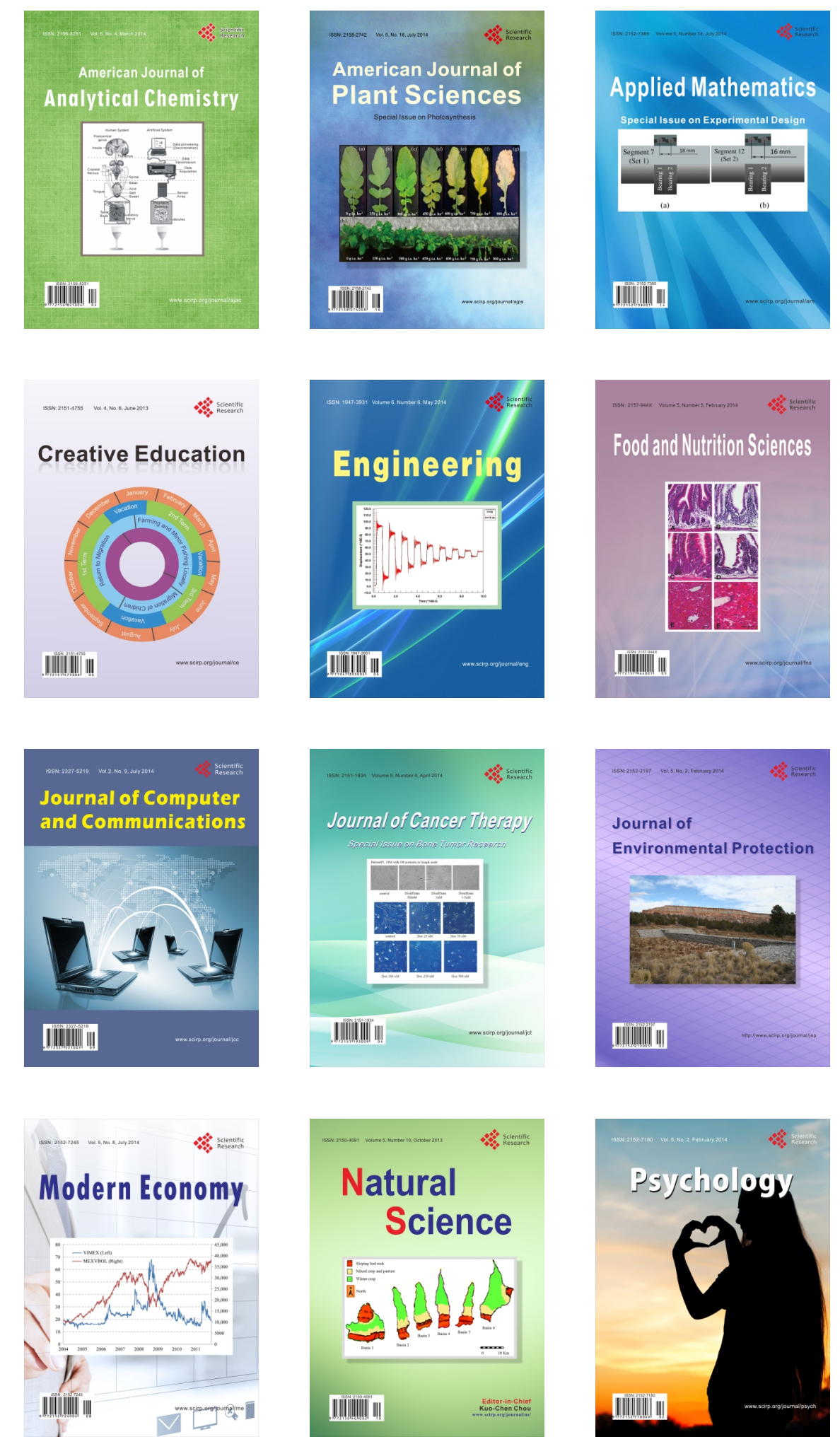